\title{
The Political of Communication and Imaging (Analysis of Theoretical Imaging the Politics in Indonesia)
}

\author{
Laode Muhamad Umran \\ Faculty of social and political sciences, Halu Oleo University, Kendari, Southeast Sulawesi, Indonesia
}

\begin{abstract}
This writing wants to focus on the construction of political imaging in Indonesia, especially on the three elections in reformation era. Political imaging as one of issues in political communication has been started on 1999 general election. It is more developed after direct election implemented on 2004 and 2009 general election. On 2009 general election, longer campaign time and the greatest number of votes system make communication and political imaging done by politician, either institutional or individual, more varied and interesting. This phenomenon is interesting and deserved to be examined deeper to find how political imaging process adopted and developed by politician in multiparty political system.
\end{abstract}

Key words: Political Imaging, Reformation General Election, Political Communication

\section{Introduction}

Interesting what is said by Gunawan Muhammad made sarcastic conclusion, which is more important; packaging, According to him, political life has been turned into a stall and outlets, shop and showroom. A future that puts public opinion polls so the size is more important than truth. And attractive appearance is more effective than achievement and social ideas that inspire (Tempo Magazine, July 27, 2008). Gunawan is not redundant with that conclusion. In many countries, the packaging or the ability to manage Imaging became the most representative explanation at the general election. For example, in Germany, in 1998, Gerhard Schroeder who so vehemently opposed the unification of Germany and never did political decisions are brave, defeated Helmut Kohl, who has led the country as chancellor for four decades, with a myriad of achievements in building the German and European Union . Kohl defeat because its image is not appropriate for the 21st century political picture pro-harmony and beauty

Instead, Schroder appeared full of grace and a smile sex appeal and the characters are smoothing. Barack Obama in the United States (2008), managed to add a reference once the political history of the world, people who became the first black President of the United States. It happened in a country that for hundreds of years to make blacks as slaves. Most likely because the image of Obama as a person who populist, embracing, honest, smart, and strong desire to change the political map of the United States, so it won impression factors or impression of voters, compared to the image of McCain, the Republican contender. The power of influence of political imagery is springing up in different countries. In our country Indonesia, as one of political imaging studies concentration in political communication, began to spread on the General Election 1999, which is growing and attractive after the application of the system of direct elections in 2004 elections, until the 2009 elections. Along with the change of political system, especially in the 2009 elections, with a longer campaign period and the majority vote system, making communication and political imagery do politicians, both institutional and individual, the more diverse and interesting, through a variety of strategies which often ignores political ethics.

First, the pure publicity to popularize themselves through community activities with the natural social setting or what it is. For example, the days of great moment, the celebration of Independence Day and others. In general, the party or candidate took the opportunity to portray what is called Nimmo (1993) as a self-political politician. Second, free publicity ride the publicity by way of utilizing the access-riding or other parties to participate popularize themselves. Appeared as a speaker at a forum participates in sporting events sponsoring social activities. Third, tie in publicity which harnesses the extraordinary news very to regular occurrence.

Tsunami events earthquake or flood for example. Candidates can portray himself as a person or party who has a high social awareness. An extraordinary event has always been major media coverage, so that participation in it is very profitable. Fourth, paid publicity the way to popularize themselves through purchases rubric or programs in the mass media. For example, the installation of advertorials, advertising, blocks time programs. Along with that, the political consultancy, which serve the imaging project from upstream to downstream, ranging from mapping the client's weaknesses and strengths, public opinion surveys, the formulation of the concept advertising, manufacture tagline, advertising materials, placement of advertisements in the media, issues management, setting up client events, growing like mushrooms in the rainy season. Among them: Fox Indonesia, Hotline Advertising, PT. Indonesian Survey Circle, Final point, and others. 
Usually this form of imaging is done politically divided into two strategies, namely Incumbent vs. Challenger. The first shows the achievement so it needs to be forwarded. The second shows the failures of government policy so that the campaign theme is to be replaced in the constitutional changes two strategies that, the imaging is done to gain the sympathy of the political and public confidence, through a variety of actions. Challenger strategy, seen from what Megawati Sukarnoputri formerly known rarely commented, let alone criticize, today criticized the government more precisely, in his expressions such as, "stocking stocking charm is not working" or "poco-poco dancers ". In addition to criticism, Megawati was also active in conducting various political safari visiting remote villages, fish auctions, market, to strengthen his political image as a figure that cares for the underprivileged.

Wiranto, who ate dramatically with the poor parched rice March 18, 2008 in Serang, Banten and advertise themselves in various mass media, if there is to be observed at least three series of poverty-themed ad Wiranto, who also criticized the government. The first series about the hardships that people have to eat parched rice. The second series, the number of poor people in Indonesia is increasing. The third series, SBY bill promises not to raise fuel. Prabowo Subiyanto also aggressively portray himself as a figure who care and take sides against the little people, through community service/politics Indonesian Farmers Association (HKTI), Market Traders Association in Indonesia, and the Great Indonesia Movement Party (Gerindra). And momentum through 100 years of National Awakening, Sutrisno Bachir appeared and public jerking through the slogan Life is deed. while for the incumbent, can be seen on imaging SBY - reflected in every Democrat advertising which showed positive results such as a decrease in the price of fuel oil (BBM), BLT, rice for the poor (Raskin), reduction in poverty and unemployment, as well as an increase in the education budget . Likewise with the tagline JK-Promise Not Give Evidence and the sooner the better, claiming success and the achievement of selfsufficiency in rice is the contribution of infrastructure development Golkar party, which he led.

In the process, the level of popularity and electability of presidential candidates published by various agencies throughout the survey in 2007, 2008 and 2009, adding rumble 2009 election contestation, including: Indo Barometer, the Indonesian Survey Institute (LSI), Indonesian Research Institute (LRI), the Institute National Survey (LSN), National Leadership Centre (NLC), the Reform Institute, Indonesian RDI, and others. Jeffrie Geovanie, expressed in his writings as a Commander of the Public Perception? Whereas, the political relations between President SBY and political parties coalition partners such as Golkar (JK) who awakened is unbalanced relationship pattern. If the government's popularity increased, automatically escalate the president's image, it does not affect the linearly against the parties in the coalition ranks.

However, if the popularity and image of the government is considered poor and declining, the parties supporting the government partners will get the impact of the downturn. After SBY ensure progress in the 2009 Presidential election, and indicated again a duet with JK, who then responded positively by JK, making constellation patterned on the 2009 Presidential election only two camps, the camp SBY and Megawati. However, in line with changes in the political constellation ahead of the 2009 presidential election, JK who had earlier been mentioned only the Vice President will take the position paired with SBY expressed willingness as candidates. Political rhythm is too quick the trigger is about $2.5 \%$ figure that was brought cadre Democratic Party. This made people offended Golkar Party. Ends, the entire leadership of the DPD Golkar JK urged forward as candidates, which is then echoed by JK. In fact, at that time, there was an attempt to preserve the SBY-JK order pair back in the 2009 presidential election. All surveys were always the couple's favor. However, the two broke up their partnership to make more dynamic political contestation.

\section{History Communications And Political Imaging In Indonesia}

Communication studies Politics after World War I, attention to Political Communication-though not in terms of political communication-began to surface with the research done in this field for the benefit of war (Dahlan, 1989). Before and during World War II, in addition to public opinion research, research propaganda technique is also growing rapidly, fueled by a German victory in many wars waged. Led lighting Minister, Joseph Goebels, Germany won the war because the war-propaganda which they practice. Goebbels propaganda success then learned, developed and practiced by the United States.

After World War II, especially in the 1950s, studies political communication is no longer influenced by strong political science, but more and more influenced by science communication, especially of mass communication. Dahlan argued that there are three things that caused it. The first is the media, the element that is a major concern of political communication, lies in the communication discipline. Second, political communication researchers more background communication experts (Nimmo, William Rivers, etc.) because communication plays a very important factor in the political process. Third, because of the interdisciplinary nature of science communication that research on political behavior more clearly understood through the study of science communication.

Entering the era of the Cold War, the practice of political communication is more influenced by political communication. Physical war is replaced by information warfare. Propaganda agitation and coloring 
date manipulation of mass media content. U.S. domination et al., to various mass media making U.S. can affect many countries. The destruction of the Soviet Union cannot be separated from the political influence of the communication. This fact makes the concentration of political communication researchers back on the effects and influence of communication, in particular-mediated communication.

After the Cold War, the political developments in various countries led to the development of a democratic political system as communication technologies make increasingly a place of political communication, especially in assessing the socialization program, agency or political candidate. Studies organized political communication can be characterized from the analysis of propaganda techniques Harold Lasswell (1927) which is now known as the father of modern communications science pioneer when it announces the results of his research on political propaganda in The American Political Science Review. Laswell's research results explain how the effects and influence of mass communication. According to him, an act of communication can be analyzed with the question of who/what to say/in channel where/to whom/with the result (effect) of what.

As though interdisciplinary disciplines; communication science, politics, sociology, psychology, history, rhetoric, and others, according to Ryfe (2001), remains a place of political communication, because of the theoretical and methodological commitments in the initial research. The commitment is in turn shaped by three main disciplines, namely: (1) Social Psychology, (2) Mass Communication Research, and (3) Political Science. Meanwhile, the boundaries of the study area is the political communication; opinion, attitudes, beliefs, politics as a process and media effects. But this restriction the flexible nature of this.

The breadth of the field of political communication studies, eventually gave rise to many definitions. Some experts/scientists who explained the definition of political communication, including Mc. Nair (2003) in an Introduction to Political Communication, Political communication defines as "purposeful communication about politics" which include: First, all forms of communications made by politicians and other political actors with the intention of achieving certain goals. Second, political communication addressed by the actors to nonpoliticians, such as voters and newspaper columnist. Third, the communication about these actors and their activities as contained in the news editorial and other forms of media on politics. While Graber (2005) defines political communication as, "the construction, sending, receiving, and processing of messages that have a significant potentially direct or indirect impact on politics.

According to Kaid (2004), by far, the best definition of political communication is a simple expression Chaffee (1975) that political communication is the role of communication in the political process of use (science) communication in the political process. Swanson and Nimmo (1990) in a New Direction in Political Communication asserted that, mainstream political communication is the study of the use of communication strategies to influence public knowledge, belief and political action. The function of political communication, according to Ghazali, are: (1) Reduce uncertainty, (2) for the purposes of the public (prospective public policies), (3) As a tool to predict and, (4) Plan and explain the strategic communication.

Along with the development of political communication studies, there was a concentration of study called Political Marketing, which specifically addresses how to sell the product of politics (policies, parties, candidates) in order to sell in the community. In a later development, Keele, Jennifer Lees-Marshment, introduced what is called the Comprehensive Political Marketing (CPM). According to Lees, the CPM does not only inform you how to campaign, but also how politicians design policies or their organizations in order to be accepted by the market (Lees-Marshment, 2001). Lees added, the concepts and techniques of marketing can not only be used as a guide for parties to communicate their products $\|$ but also can guide how the party will determine what they produce and how they should behave towards their political market.

Comprehensive Political Marketing (CPM) as a theoretical framework has key principles as follows: First, the CPM looked at political marketing is more than just political communication. Second, CPM applying marketing approach to the whole behavior of political organization or party, not just about how they campaign or how campaigns are organized, but also on how the parties to design their products. To that end, the analysis of political marketing in the behavior surrounding the CPM party from start to finish political election cycle, not merely during the campaign, and also covers various aspects such as aspects of the party leadership, the party's MPs, membership, organizational structure, party symbols , the party constitution and party activities. Third, the CPM uses concepts such as the orientation of product marketing, sales or market, not just the marketing techniques such as market intelligence, product design or promotion.

Fourth, CPM to integrates political science in its analysis and marketing concepts used for the adjustment of the existing understanding of the traditional discussion about political parties. Fifth, CPM to adopted and adjust marketing theory theories that the different nature of world politics. Marketing concepts of product, price, place and promotion adjusted such that in accordance with the party's political activities. The Communication of politics in Indonesia, the communication of politics began to develop since the fall of the New Order in 1998. Although the practice of political communication has been made by political actors, for example, in political speeches of President Sukarno and to campaign slogans like;-Leader of the Revolution, 
Crush Malaysia, Nasakom etc. But the political rhetoric of Sukarno full power of hypnosis, find result of climax when there G-30-S/PKI.

Opinion balancing of other elite including students started popping up and managed to shift political communication excellence Sukarno. In the New Order era, the success of Suharto exploit popular discontent over his leadership before, the issues and the latent threat of communist-implement Pancasila and the Constitution 45 a genuine and consistent communication is the key to success in politics Suharto, in gaining the sympathy and support of the people. Although the practice of political communication is run by political actors in the era of the Old Order and New Order, but the study of political communication is not experienced significant development

According to Alwi Dahlan (1989), it occurs because the science of political communication is still considered as a whole should be examined. If it is taught, the courses in this field cannot provide an adequate understanding of the process of political communication. While majoring in communication at various universities is also not steeped in political communication in particular. Communication scientists were reluctant to conduct research related to politics, except descriptive or normative. Reforms in 1998 opened a new chapter in the practice of political communication in Indonesia. Freedom of speech and democracy are the foundation for every person to express his ideas, including in politics. Image processing, persuasion and political rhetoric performed quite well by political actors to gain public sympathy.

Gazali (2004) divides the focus of study into two Political Communications that is, traditional focus and new focus. Gazali view categorization core focus is the study of traditional political communication is communication of politics that can be seen in a more concise formulation Lasweel. While the focus of a new study of political communication, is the politics of communication are well represented in the statement of Chaffee; who gets to say what to whom? Gazali explain at least twenty-one field of study that can be done in this country. All areas of study are closely related to each other even though it is divided into three major groups; focuses traditional (communication of politics), new focuses (mostly non-mediated activities) and the politics of communications. Model expanding range of issues in the field of political communication. For example, researchers are not only limited to the study of public opinion on political communication, but also study the actions of citizens. Similarly, the forms of media that are typically not included in political communication research such as movies, folk songs, television shows, radio programs, and even rumors, should be seen as a viable expression of political communication. In this model, Gazali also stressed the need to explore a number of fields such as the study of satisfaction (gratification) and the use of the media attention on the active participation of citizens in relation to selective exposure, media type, content selection, and feedback to the citizens of media content.

Political imaging, image is the world according to our perception or the pictures in our heads (Water Lippman, 1965), which is a description of reality, it may be is not in accordance with reality. The image is formed based on information received through various media, particularly the print and electronic media, which works to form, maintain, or redefine the image. From the standpoint of social science, one theoretical approach of the creation of the image is the impression management where the image is viewed as an impression of a person or an organization against another person or organization.

According to Nimmo (1978), image is everything related the everyday some one situations: regarding knowledge, feelings and inclinations towards something. So the image can be changed with the passage of the time. The theory states that building image, the image will be visible or formed through the process of receiving a physical (sensory), entered into a sieve attention (attention filters), and from it generates a message that can be seen and understood (perceived message), which is then transformed into perceptual and eventually form the image (Wayne De Lozier, 1976). Furthermore, Nimmo (2000) states that, the image of someone about politics are intertwined through the thoughts, feelings and subjective sanctity will give him satisfaction, which have at least three functions, namely: (1) no matter how right or wrong, complete or incomplete, knowledge about the politics, gave way to a person to understand a particular political event; (2) General likes and dislikes a person in the image of the present political basis for assessing the political object; (3) Person's self image gave way to connect themselves with others. As part of the political communication, political imagery was done by persuasive to expand shaded area between the expectations of candidates with voters.

Corner and Peels figures recorded both clean and problematic (notorious) substantially equally worked hard to build the image of politics to influence voters, because the image has been the most decisive factor of success or failure of a campaign trip. Gunter Schweiger and Michaela Adami (1999) argue the image of an overall picture that is in the heads of voters about candidates and programs. These authors argue that the decision-making process is not always influenced by voter knowledge about the programs by the parties and the information to build a political brand, but the process can be influenced by the strong impression and no rational evaluation criteria (criteria used irrational voters in evaluating the candidates/parties).

Bruce Newman (1994) in his book The Marketing of the President: Political Marketing as Campaign Strategy suggests that the current political campaign has been run using the rules of business, including 
marketing principles, namely: marketing research, market segmentation, targeting, positioning, strategy development and implementation. That is, changes in the political democracy have shown that the tendency towards aesthetic stylization that takes place naturally and cannot be avoided in a direct election system. This tendency of the natural that explains why the image, which is owned by the candidate to the voters increasingly influential in determining their political choice. Responding to political developments in the arena of democracy imaging premises, Gazali assess, in a modest level of political imagery including political marketing, as candidates resemble sells a product marketed. If more sophisticated, can be categorized as political communication, namely politicians promoting policies substantially in ways that captivate the public. As the most important element to be considered in determining voter choice, it is not surprising that politicians exploit the concept of imagery to bridge the gap between the behavior of politicians and voters understand what is actually stored in the minds of the voters (Nimmo, 1974 quoted from Newman, 1999).

Imagery in politics is actually more than just a strategy to show the candidate to voters. But it also relates to the impression held by either the voters believed to be the right thing or not. That is, the image is more than just a message that is made by the candidate or the picture made by the voters, but the image of a negotiation, evaluation and construction by the candidates and voters in a joint venture. In other words, the confidence of voters about candidates by interaction or interdependence between committed by candidates and voters. Thus the image is a transaction between a candidate's strategies in creating a personal impression with existing beliefs in the minds of the voters. According to McGinnis, (1970) in Kavanagh (1995), voters actually see the candidates not based on reality rather than a genuine chemical process between voter and candidate image (picture imaginary).

Good image, by itself will increase the popularity and electability candidate, and vice versa. Thus, it is not wrong if politicians-imaging $\|$ political somersault. As more and can show a good image, the opportunity to reap greater voter support. However, in the context of image formation, not least the loss of the power strength of the attention (eye catching). The image previously expected to create shock, stimulation, and slap unexpected information (entropy) turns into the unexpected repetition (redundancy).

Aesthetics images and tasteful, because running out of vocabulary signs, eventually becoming the images cheap and shallow. In the context of political communication, it takes place when the political images appear in large quantities, high frequency, and time rapidly causing the message no longer attracts public attention. According to Amir Piliang Yasrif, this process can be seen in some logic, namely: First, the logic of velocity (speed), while there was a tendency among the winning team (presidential vice) mobilize all potentials and sign vocabulary, imagery, and narrative in a compacted time so that at a certain point saturation raises public. Second, the logic of ecstasy of communication, the ecstasy of self-image in appearance candidate in an all-out-with the potential to mobilize all existing image, even images that have "exceeded" the capacity, capability, competence, and reality concerned-without considering the relation between exposure time and the condition of mass psychology.

Third, the logic of the spectacle, which presidential and vice presidential political campaign that has been shifted toward the form of the mass spectacle, by following the principles and logic of spectacle in general, that gives pleasure, amusement, contentment as much as possible, to explore the effects of cuteness, humor, and -dramatization that are fake-without any space to internalize the political meanings are true. Fourth, the logic of simulacrum, namely exploration repertory mark and image of excess and "crossed the line" so that the image of politics and reality offered vice president-there are actually very deep ravine. This is the candidate that is imaged "simple", "earthy", and "populist", while living in luxury and abundance of possessions. Fifth, the logic mithologisation. Various forms of myth, fantasy, fairy tales, fiction, imagination, hallucination which is not part of the reality of a vice-president-now, appear as if the "reality" really is. These are the myths about ancestry, national origin, success or greatness of the past, which is not a present reality. Sixth, the logic of perfect imaging, which is the depiction of the image of a vice-presidential candidate as a perfect figure, as if without a flaw, a weakness, and sin. Seventh, the logic of popular culture, which displays the images of the shallow, surface, and in order to bring a popular candidate and running mate to the popular masses.

This is the political ads that use images of school children, subculture groups, youth culture, slang, popular languages, and celebrity style to appeal to the masses. Eighth, the logic of obesity, which is too dense, fast, and high-frequency images aired political commercials, giving rise to a condition too inflating marks and information, which is not comparable with the public's ability to perceive, receive, read, interpret, and internalize it in a stance or political preference. So to avoid this process of imaging, imaging needed management is effective so that on one side the image can attract public attention and sympathy, on the other hand is able to also become a means of political education. Persuasion, Imaging and Management of Public Opinion As part of persuasion, imaging can be done through a variety of strategies, ranging from the most simple/traditional to the most modern. Positive imaging will also be a positive influence on attitudes, beliefs and behavior of people who dipersuasi, and vice versa. Imaging in political communication depends on the efforts of persuasion performed in accordance with the objectives desired by the persuader to persuasion. In this context, 
management is required imaging or the structuring and management of an activity that has a positive impact (good) against the good name (imaging) individuals or groups (organizations, parties, etc).

In imaging, there are two basic elements: (1) positioning, what was placed political actors' political message recipient in mind. This concept can be defined as a relationship between a products made by the company that produced the specific segments in the market (Newman, 1999). Ries \& Trout (2002:3) defines asput-positioning the product in the minds of consumers. Even so the positioning is not something that is done to the product itself, but rather placing the product in the minds of potential consumers; (2) memory, impression of how political actors ' on -hold in the minds of the political message recipients. Humans are intrinsically cognitive miser (stingy allocate cognitive resources) and often selects information to be stored in memory, only the things that was considered important was the one who saved him , the other being discarded. Moreover, in a world that is filled with messages that are exchanged (over communicated society), humans have some kind of mechanism called oversimplified mind-mind which absorbs only the messages it thinks are not too complicated and simple. To approach the above two basic elements, it takes persuasion or attempt to convince others to act and act as expected communicator without coercion (Widjaja, 2002:67). Meanwhile, according to Johnston (1994 ), persuasion is a transactional process between two or more people where there is an attempt to reconstruct reality through the exchange of symbolic meanings which then produce changes in beliefs, attitudes or behavior and voluntarily.

From the above definition, we can conclude that persuasion in principle is every act of communication that is intended to change or reinforce attitudes, beliefs and behavior voluntarily audience so in line with what is expected communicator. Simons (1976) identify elements that can help us define what is referred to as persuasion, namely: (a) human communication. Every persuasion is inter-human communication verbal and non-verbal, oral or written, express or implied, direct face to face or through various forms of media, (b) attempted influence. Communications made in persuasion always trying to influence others. Therefore, persuasion can be called as a manipulative action. Even so, persuasion still gives the option on his receivers make him different from coercion coercive; (c) Beliefs, Values or Attitudes. Who try to be influenced in persuasive communication is Faith (Beliefs; judgment about what is true or probable), Value (Values; abstract judgments about such matters as what is moral, important, beautiful) and attitudes, judgment about how to act.

Based on the above elements, Simmons defines persuasion as: "Human communication/designed to influence/others/by modifying their beliefs, values, or attitudes". Because persuasion is essentially an act of communication, then Larson (1986), in order to explain the elements that exist and need to be considered in any process of persuasion, wearing SMCR communication model developed by Shannon and Weaver namely: source, message, channel and receiver. Associated with the source, aristotle claimed, persuasion can be built on the basis of the reputation or credibility (ethos). Furthermore, ethos can be built through the message being delivered, could be a logical argument (logos) or using an emotional approach (pathos).

Quintilian asserted, in addition to be-good speaker, a persuader must-good man (Larson, 1986). Related messages, Cicero stated there are five elements of persuasive speaking-namely: (1) collecting or finding evidence and arguments (inventing or discovering evidence and arguments), (2) organize the arguments and evidence that (organizing them); (3) boxed evidence and arguments are interesting (styling them artistically), (4) to remember (memorizing) and (5) submit evidence and argument as well as possible (delivering them skillfully). Onong Uchjana Effendy (2002) to suggest some persuasive communication techniques, namely: (1) Engineering association, presentation of message communication by way of laying an object or event that attracted the attention of the audience; (2) Integration technique, the ability of communicators to blend with the communicant. That is the approach to verbal or non- verbal communicator puts him feel the same way with the communicant, (3) Engineering discipline, influence others by giving the lure or reward from the communicator to the communicant, (4) Technique level, composing messages as precisely as possible in order to attract, good to hear or read and in the end will lead the audience to act as desired communicator. 5) Techniques red herring, art a communicator to victory in the debate with a weak argument to deflect divert then little by little to the aspect mastered in order to be used as a powerful weapon in attacking the opponent. This technique is used when the communicator in a state of urgency.

In the process of political persuasion for imaging, cognitive and affective elements should be placed simultaneously, among other elements feelings (feelings of like or dislike towards a concept or object), the element of trust (an overview of knowledge about certain objects and concepts) and behavioral elements (how to respond concept or object). Furthermore, the image can be assumed as a model of the process of creating imagery in the science of psychology is described as a process in which the receiver of the message construct their own meaning (of the observations subject) of the reality he saw, or symbol that is sent from the sender of the message (Grunig, 1993 quoted by Newman, 1999). Thus it is understandable that the image is a complete picture of a figure /candidate, which is stored in the minds of voters.

So that, should to attention about the consistency between the work program offered by a symbol that is created and submitted to the voters, because it is not easy building a political image. Many factors can affect 
the image, which is perceived by the community and out of control. Among them is a factor of political competitors, and individuals such as religious background, race, ethnicity, education, gender, location, and age, which existed before the party/political candidate trying to put their image in the memory of voters.

The image is formed based on the information received by the public, either directly or through the mass media. Public image of the manifest as cognitive consequences of communication. Roberts (1977) stated that the communication does not directly cause a certain opinion or behavior, but it tends to affect the way audiences about environmental organizing its image and the image that is influencing public opinion or behavior. Political image can be formulated as a picture of the political (power, authority, authority, conflict and consensus) that have meaning, although not always in accordance with the actual reality. Political image composed through meaningful perceptions about politics symptoms and then declare that meaning through beliefs, values, and expectations in the form of personal opinion which may further develop into public opinion.

The politicians, the main candidates are very interested in formation image. So it is not excessive, if the time before the 2009 Presidential election, the figures appear, try hard to create and sustain political action that can generate a satisfactory image, so that the support of public opinion can be obtained from the people as audiences of political communication. Political image includes several things: (1) a person's entire political knowledge (cognitive), whether true or false, (2) all preference (affective) attached to a particular stage of the political events of interest, (3) all hope that people have about what might happen if he behaves in a way changing the object in that situation. With this, the image of politics is always changing according to the changing political knowledge and political experience of a person.

A mongo the imaging media politics very prominent today is the mass media industry. The main strength of the media in the information age is the ability of the media in constructing reality. That is, the strength of the pack there is a wide range of issues, so it stands out to the surface and eventually become a public debate (public discourse) is interesting. That is, the control over the media will be the entrance in the packaging and control of public opinion. Furthermore, with control of public opinion is expected to be easier to direct preferences in accordance with the expected audience. Opinion in the perspective of communication is seen as an active response to the stimulus response is constructed through a growing personal interpretation of imagery and imagery contributes. Therefore, a response construction opinion, it is very strategies if politicians are fighting to have the attention on the packaging of political opinion. At the very least, there are three main components in an opinion, namely: First, the conviction that matter is composed of credulity or trust and not against something. With marketing, the audience will be led to believe what the concept and offer candidates.

The more of larger the audience the candidate's confidence, the growing opinion will be more positive. Second, in the opinion also contained values shaped the values of well-being (welfare values) and the values of deference (deference value). Welfare values include search wellbeing, prosperity, and skills. While the values of deference among other plantings respect, a reputation for moral rectitude, attention and popularity and power. By understanding the components of that value, if the candidate should understand the true opinion cannot be allowed to flow freely, but must be constructed. Of course with an elegant ways. Third, the opinion also consists of components expectations. Namely components associated with co native elements. This is an aspect of personal imagery and interpretation processes are sometimes confused by psychologists as an impulse, desire (volition) and hard effort or striving. Awareness of public opinion is to pack the awareness and the desire to harmonize efforts attainment of the ideal type of an ideal type structure with the expected audience of voters. That is, the widespread expectation shading areas between candidates with voters, then the chances of a candidate to win the battle larger image. In various mass communication science literature explained that, the political message conveyed by the mass media is not the true reality, but the reality of the media or the reality of the second hand (second hand reality), made by reporters and editors who cultivate political events into political news, through the process screening and selection. Based on the image that may not be right, can awaken the audience a general idea of self-called stereotypes.

Stereotypes is processed, organized and stored as political information by audiences who subsequently formed a political image. This is where the danger of the influence of the mass media which is seen as an institution that threatens the values of truth and human rationality. Ernest van den Haag (1968) criticized scathingly, that the mass media in the end alienate people from personal experience, and broaden the moral isolation and the reality of their own. Social critics also concluded that the mass media had "cheated" the audience, by presenting a false image of the politics of the work of reporters and editors.

Despite the reality that the media is not polished accordance with the facts and reality of the truth, but still many people in the community (audience) who tend to take for granted the information from the mass media, either due to low level of education or omissions. This evidence suggests that the mass media can shape the political image of the individuals who became a mass media audience in the direction he wanted. The media can also steer public in maintaining that image already has. Secondly it is done by the mass media through the process of gate keeping and agenda setting. The mass media is also often referred to as a mirror of society. Lee Lowinger (1968) have presented a theory of mass communication is referred to as reflective-projective theory. 
The basic assumption of this theory is that the mass media is a mirror that reflects an image of society that give rise to many interpretations. Precisely that every person can protect themselves and their image. The media reflects society's image, and vice versa audience projecting its image on the media presentation

Then it can be explained that the political news, political leaders, political parties and political policies can lead to different interpretations and different political image for each person. besides the mass media of political communication perspective, not only mirrors the ambiguous political society, but also the mass media can be termed as the cracked mirror of political society, because it is not able to reflect all the political realities that exist in society as a whole, right and true. News media is simply a mosaic of pieces of events that occur in the community. Nevertheless, the media still has a strong influence in shaping the perception of politics and political image of audience.

\section{The Mass Of Media And Political Communication}

One of the important actors in modern democracies is the mass media. In the majority of people who use the media as a tool to obtain information, the strong influence of media agenda setting. Society makes choices and political decisions based on information obtained through the media. Knowingly or not by the users of media, the media setting the agenda for the field of direct political thoughts and attitudes of the politicalmedia users (McCombs and Shaw, 1991). This conditions to bring the mass media as the dominant source not only for individuals but also for society in obtaining an overview and images of social reality. This assumption is supported by a variety of theories about media and public relations among others, stimulus response, agenda setting, the spiral of silence, cultivation and others. These theories generally explain that, if the media put pressure on an event, then it will affect the audience to consider it important. In this perspective, the media does not specify what to think, but what to think about. The importance of the mass media (such as radio, news papers, magazines and television) the most obvious is its ability to reach an unlimited number of audiences.

The development of the mass media, according to J. Keane, in his book, The Media and Democracy (1991), always hand in hand with democratic aspirations and struggle for political power. The mass media have become the focus of recent political activity complexity. Traditional Democratic previously focused on, change in fragmentation. With the situation is no less complicated and dynamic, the media and the political will situation continues to evolve toward a mutually bonded to each other. Although the use of media in the process of communication and other forms of communication such as agitation, propaganda, public relations and campaign, does not directly lead to a certain behavior, but it tends to affect the ways humans organize their political image and build public opinion. That is what will affect the way human thought (opinionated) and behave. Mcluhan (1964) mentions that the media is an extension of the human senses.

Mcluhan view of the extension of the theory known as the senses (sense extension theory). Mass media to convey the message that came and actual variety of social and political environments. Newspapers as print media for example are a medium to know the actual political events that occurred throughout the world. Radio and television as well as electronic media becomes a means to follow the political events that were happening or has just happened is far from the reach of the five-senses. Mcluhan even mention that thanks to the mass media, especially television, world village universe of experience and experience is delivered instantly felt together.

The support of the media for a political activity is not only based on the assumption of the magnitude of a political event, but also the political value of the incident. Political value is mainly concerned with its own media interests, and the interests of society, as consumers of the media or the public. A political events will very likely be addressed in different ways by various media, among others, at the laying of the news (primary or regular), the volume of news and engineering news-tendency, in which the contents of the media regarding the incident is very likely get a different response by the public media different. Important aspects of mass media messages are factors other than the ability of the media to shape public opinion. The existence of public opinion with the snowball effect is very likely to encourage attitudes and behaviors over a certain political issues. According Chaffe, the mass media is an important source of political information, not just complementary interpersonal communication, but support the growth of a person or an institution of politics, although in the end that determines whether or not the media is influential media users themselves.

Meanwhile, according to Keller quoted by Czudnowski (1983), any person can become famous in 15 minutes, especially on television. In addition to boosting the popularity, the media is also a major source of information and stimulation political meaning. Meanwhile, according to Harsono, a number of aspects that make an important mass media in political life are: (1) a very wide-reaching power in disseminating political information; are able to pass through boundaries (geographical), and age group, gender, socio-economic status (demographic ), as well as disagreement and orientation (psychographics). Thus mediated political issues of common concern in a variety of places and circles; (2) Ability to multiply message outstanding. A political event can be doubled according to the number preaching newspapers, tabloids, magazines are printed; may also be repeated in accordance with the requirements of broadcasting; (3) Each media discourse can view corresponding political events respectively. Its editorial policy determines the appearance of the content of 
political events reported; (4) With the function of setting its agenda, the media has a very broad opportunity (even almost without limit) to proclaim a political event, in accordance with their respective policies. Every political event can be broadcast or not broadcast. What is clear, not necessarily political news media agenda is a public agenda; (5) Coverage of political events by a media typically associated with other media to form a chain of information.

This adds to the strength of its own in the dissemination of information and its impact on public policy. In the current political phenomenon, Deddy N Hidayat assumes that, the press has been transformed into a media-driven politics. In a sense, every political momentum is impossible to deny the presence of the press. In its function as a medium politics driven, press liaison function between the political elite and citizens. A dominant function formerly performed by the party or political groups. In many ways, the bridge function is taken over more and more press. The process of producing and reproducing a variety of political resources, such as collecting and maintaining community support in the elections, mobilizing public support for a policy, reverse image of the candidate's performance, and so on, many bridged, or even driven by the interests and norms prevailing in the market media industry (Deddy Hidayat, 2004). Efforts to build the political elite positioning through the press is legitimate done. Firstly because the phenomenon has not been fully resolved floating mass by the political elite. As a result, many political elite turned to the media, because the media can "draw" them, while building a certain image as desired into the community. Second, the political fight over resources, the press also "used" in the sense used as a channel to mobilize opinion interests. In general, political communication always discuss about the position of the media in the public domain.

The media is very important because it is located right in the center of the vortex interest groups, is also important as a means of forming public opinion. In modern political communication, the media plays an important role. But the media never worked (performing) in an empty space. There are various models of media interaction with other elements in political communication. Some of the communication model that connects the media with elements of political communication. It is understood that McNair considers media as central elements of political communication-a kind of gatekeeper for all political message. All politics are considered mediated communication. In many developed countries where the media to reach all levels of society. Another model that describes the position of the mass communication media McQuail illustrates that the media is strongly influenced by the main purpose media itself. The main purposes of media that have been identified are: (1) provide a profit to the owners of both investors and shareholders, (2) an ideal destination 'the cultural, social and political, (3) maximize the audience and satisfying, and (4) maximize revenue advertising.

These objectives are often contradictory-back and full of rare harmony among the four. Also recognized that there are four external factors which means that there is work culture and other purposes of the media, particularly those oriented or profit management, technical or skill oriented, or those who give priority to the goals of communication. Media elements influenced by elements of political communication, namely: government institutions, civil society and the market. Ideal conditions expected by political communication are the creation of a balance between the four elements. In other words, there is no dominant element among the four. In the triangle models Gazali, Media should be right in the middle, not shifted to the corner of one of the elements. When no one element dominates the other elements, the quality of political communication will be reduced - which in turn would adversely affect all elements of political communication itself.

In political communication in Indonesia (Gazali, 2005) From Gazali models is understandable that political communication is not always mediated. There is also a political communication channel that directly connects the market (capital owners, advertisers, and clients), government and the community. Nonetheless, Gazali keep putting media as gatekeeper or communication channels are important in politics because of the ability of the media to amplify the effect-clicking a political message. According to Habermas, the media initially set up to be part of the public sphere, but then commercialized a commodity which is distributed in bulk and sells a mass audiencefor the sake of advertising company. This in turn keeps the media from its original role as a public sphere, the concept of the public sphere is considered by Boyd-Barrett has some disadvantages, among which are excessive Habermas attention on political news as well as excesses Habermas in exaggerating fraud arising from the commercialization of the mass media in the 19th and early 20th century.

Regardless of these shortcomings, some demand from the concept of the public sphere is good enough to put the proper function of the media in political communication amongst other elements. Based on the concept of the public sphere-enhanced, McNair gave the five functions of the media in a democratic society the ideal: (1) monitoring functions: to provide information to the public about what is going on in the community, (2) educating function give the meaning of honesty and the significance of the facts that occurred. Journalists must maintain objectivity because of their value as educators' depending on how they choose the issue/publication of discourse; (3) provide a platform to the public political discourse, facilitate/ accommodate the formation of public opinion and returns it to the public opinion, including the giving where the various opinions which contradict each other, without compromising democratic values; (4) watchdog function: to publish political institutions and government institutions, creating openness (transparency) in the public 
institutions and, (5) advocacy functions be a channel for advocacy politics. Parties, for example, require a tool to articulate their policies and programs to the public, and therefore the media should be open to all parties. Furthermore, several media generally print media are actively fighting for one of the parties in sensitive situations such as elections.

\section{Conclusions}

The majority of the political communication process is mediated politics or even media-driven politics. That is, the process of producing and reproducing a variety of political resources, such as raising and gather political support in elections, manipulate images, and so on, can be bridged or even driven by the media industry. So successful politician in this era will be largely determined by its ability to build a network or access to the media, to then manage the opinions, perceptions, win sympathy, and so on through the media.

Mc Nair stated that, in the era of the mediation, the function of the mass media in political communication can be a transmitter (transmitters) political messages from parties outside of himself, as well as a sender (senders) political messages made (constructed) by the reporter to audience. This means that, theoretically, the relationship between politicians and the media could walk harmony. The mass media can mediate the political activities of the politicians to the people. And conversely, the media can also mediate opinions, demands, or the public reaction to politicians. The mass media is the traffic space for all sorts of ideas that are of interest to many people. Of the many media that can mediate political activity, which is considered the most effective is television. The phenomenon is then led to the term tale-politics. Tele-politics is a new phenomenon that marked the shifting role of political parties and the emergence of the dominance of the mass media-especially television-in reaching voters. Television emerged as a new force that is more massive in conveying political information to the public. The survey data shows that most people in Indonesian political information through television (87\%). In contrast to conventional political meetings that require the presence of a person, through television interaction is more one-way traffic communication, more practical and less troublesome voters. In Indonesia, the influence of television has been so strong united with everyday people. 2004 World Bank data show, there is a 65 percent owner of the television households in Indonesia. Audio-visual media forms is interesting and full of the magic tube makes it more loved than the other cultural products, such as books. Because entertainment is presented able to attract the majority of the population to pursue television in their daily activities.

According to the National Socio-Economic Survey (NSES) in 2006, over three-quarters (86 percent) of the population aged 10 years and over in Indonesia have regular activities within a week following the television show. As for literacy activities be lower, i.e. 68 per cent of the total population of that age to read a variety of reading materials for the week. Variety occupied reading includes news papers, magazines, textbooks, book knowledge beyond textbooks and story books. Still according to the Ponca, Symptoms low interest in books began when a private television boom in the country in the early 90's. When the first Indonesian private television was born at that time, almost no one expected if the next decade there will be a dozen even dozens of other private television stations such as the present with a variety of impressions.

\section{References}

[1] Amal, Ichsanul. 1998. Teori-Teori Mutakhir Partai Politik. Yogyakarta: Tiara Wacana.

[2] Ali, Fachri, dkk. 2008. Kalla dan Perdamaian Aceh. Jakarta: LSPEU Indonesia.

[3] Arifin, Anwar.2008. Opini Publik. Jakarta: Pustaka Indonesia

[4] Firmanza. 2007. Marketing Politik. Jakarta: Yayasan Obor Indonesia

[5] Harun, Rochajat dan Sumarno. 2006. Komunikasi Politik, Suatu Pengantar. Jakarta: Mandarmaju

[6] Haryatmoko. 2003. Etika Politik dan Kekuasaan. Jakarta: Penerbit buku Kompas

[7] Hamad, Ibnu. 2003. Menggugat Pers dan Partai Politik dalam Panggung Wacana Politik Indonesia dalam Mahrus Irsyam dan Lili Romli (ed). Menggugat Partai Politik. Jakarta: Laboratorium Ilmu Politik FISIP Universitas Indonesia

[8] Hidayat, Dedy N. dkk. 2000. Pers dalam "Revolusi Mei”, Runtuhnya Sebuah Hegemoni, Jakarta: PT Gramedia Pustaka Utama

[9] Hidayat, Dedy N. dkk 2004. Menjadi Presiden dalam Era Media Presidency, dalam Rendro Dhani, Centang Perenang Manajemen Komunikasi Kepresidenan dari Soekarno Sampai Megawati. Jakarta: LP3ES

[10] JA, Denny. 2006. Melewati Perubahan Sebuah Catatan Atas Transisi Demokrasi Indonesia. Yogyakarta: LKiS

[11] Jamieson, Kathleen Hall. 1996. Packaging Presidency, A History end Criticism of Presidential Campaign Advertising. Third Edition. Oxford: Oxford University Press. Volume 2, No. 4, Desember 2009 ISSN: 1979 - 0899X

[12] Kavanagh, Dennis. 1997. Ellection Campaigning: The New Marketing of Politics. United Kingdom Blackwell

[13] Lance, Bennet \& Robert Entman (ed). 2001. Mediated Politics: Communication in The Future of Democracy. Cambrige: Cambrige University Press

[14] Lesmana, Tjipta. 2008. Dari Soekarno Sampai SBY, Intrik dan Lobi Politik Para Penguasa, Jakarta: Gramedia Pustaka Utama.

[15] Littlejohn, Stephen W. \& Foos, Karen A. 2005. Theories of Human Communication. Eight Edition. London: Thomson Wadsworth

[16] Lilleker, Darren G, \& Less-Marshment, Jennifer. (ed). 2005. Political Marketing, A Comparative Perspective. Manchester: Manchester University Press

[17] Lichtenberg, Judith. 1990. Democracy and The Mass Media. Cambridge: Cambridge University Press

[18] McNair, Brian. 1995. An Introduction to Political Communication. London: Routledge McQuail, Denis. 1987. Mass Communication Theory. 2nd Edition. London: Sage Publications

[19] Newman, Bruce. I., (ed). 1999. The Handbook of Political Marketing. London: Sage Publications 
[20] Nimmo, Dan. 2006. Komunikasi Politik, Khalayak dan Efek. Bandung: Remaja Rosdakarya Nursal, Ahmad, Political Marketing, Strategi Memenangkan Pemilu: Sebuah Pendekatan Baru Kampanye Pemilihan DPR, DPD, Presiden, Gramedia, 2004

[21] Pfetsch, Barbara and Esser Frank, (ed). 2004. Comparing Political Communication, Theories, Cases, and Challenges. Cambridge: Cambridge University Press

[22] Rakhmat, Jalaluddin. 2005. Psikologi Komunikasi (Edisi Revisi). Bandung: Remaja Rosdakarya.

[23] Suwardi, Harsono. 2004. Konstruksi Realitas Politik dalam Media Massa. (Dalam Kata Pengantar) Hamad, Ibnu. 2004. Konstruksi Komunikasi Politik dalam Media Massa (Sebuah Studi Critical Discourse Analysis Terhadap Berita-Berita Politik). Jakarta: Granit

[24] Suwardi, Harsono, 2002. Politik, Demorasi dan Manajemen Komunikasi. Yogyakarta: Galang Press Suyanto dan Sutinah (ed) 2005

[25] Baran, Stanley J \& Denni K. Davis. 2000. Mass Communication Theory, Foundation, Ferment, dan Future. Wadsorth. 